\title{
Ulike dødsårsaker - ulike sorggrupper Refleksjoner om sorggruppers betydning
} Av Renate Gronvold Bugge 
VED ARBEID MED SORGGRUPPER er det viktig å ha en forståelse av sorgens forløp, både smerten som lindres etter hvert som livskvalitet gienvinnes, og den kompliserte sorgen, som hindrer videre utvikling og vekst i møtet med det videre livet. Det vil være behov for spesifikk faglig kompetanse ved bistand til personer med komplisert sorg, mens det kan være tilstrekkelig med likemannsstøtte der sorggruppene består av deltagere som har normale reaksioner og som etter hvert finner fotfeste igien i livet.

Mange kan ha motstand mot å delta i sorggrupper fordi det kjennes fremmed å dele sine følelser med andre, mens det for andre oppleves som støtte å kjenne igien egne reaksjoner i det andre forteller. Uansett er det viktig at ledere av sorggrupper kienner til nyere sorgforskning, som vektlegger at det ikke er en bestemt oppskrift på sorg. Sørgende bør ikke få høre at «nå er du i benektingsfasen,

\section{De etterlatte} bærer sorgen ulikt. For alle gjelder det å finne nye måter med tapet å leve videre

bare vent så vil du etter hvert oppleve at tilpasningsfasen inntrer». Jeg setter dette med vilie litt på spissen fordi jeg flere ganger har opplevd at hielpere har en altfor bestemt oppfatning om hvordan sorgen forløper og dermed kan komme i skade for å påføre de berørte en ekstra belastning dersom deres måte å sørge på ikke følger «oppskriften». Sorgens intensitet måles heller ikke i antall tårer. De etterlatte bærer sorgen ulikt. Men for alle gielder det å finne nye måter å leve videre med tapet. Det er et tungt arbeid både emosjonelt og kognitivt. Det er i dette perspektivet sorggruppene kan bidra ved å tilby muligheter for støtte og bearbeiding slik at tapet kan integreres som en del av det videre livet. Et liv som aldri kan bli det samme som før, men som allikevel kan være meningsfylt.

Tilrettelegging og form kan variere sterkt avhengig av type dødsfall, omstendigheter rundt dødsfallet, relasion til avdøde og alder på etterlatte. I denne artikkelen vil jeg med utgangspunkt i egen klinisk erfaring, etter møter med etterlatte i ulike sammenhenger og som veileder for sorggruppeledere i Fransiskushjelpen i Oslo, diskutere hvordan ulike typer av sorggrupper kan være til hielp

\section{ABSTRACT}

Dødsårsak, relasjon og alder har betydning for hvordan dødsfallet oppleves og påvirker sorgprosessen. Det er derfor viktige kriterier for hvordan sorggruppetilbudet, i utvidet forstand, utformes. Terapeutiske grupper er som regel lukkede grupper, som har forutsigbare rammer over et gitt tidsrom. Målsettingen er å gi etterlatte mulighet til å integrere tapet i eget liv og etter hvert erkjenne endring og utviklingsmuligheter, som kan gi mening for det videre livet.

Fagstyrte grupper er ofte i offentlig regi og krever kompetanse innenfor sorgarbeid, gruppeprosesser og sorg-/traumereaksjoner. Likemannsgrupper defineres ofte som en møteplass, der likesinnede kan dele erfaringer. Dersom disse gruppene er åpne grupper, både hva deltagelse og tidsrom angår, kan det for noen vanskeliggjøre å komme videre i sin sorgprosess. Egne opplevelser kan reaktiveres når nye begynner i gruppen. Åpne grupper kan også komme til å erstatte eget nettverk.

Etterlatte etter selvmord forteller at det er vanskelig å delta i blandete sorggrupper, ettersom sorgen etter selvmord har så mange andre dimensjoner enn selve tapet. Det samme kan være tilfelle for dem som har mistet pårørende gjennom voldshandlinger.

I denne artikkelen omtales også en utvidet forståelse av sorggrupper til å gjelde begrensede gruppeintervensjoner spesielt etter brå, uventete dødsfall. Klassesamling og kollektive samlinger av etterlatte etter større ulykker omtales.

When offering groups to support the processes of loss and grieving we have to be aware that the cause of death and the relationships and age of those involved have consequences for the grieving process. It is important to take this into account when offering such groups. Therapeutic groups work with agreed aims and with predictable structures, such as time boundaries. These groups offer a possibility for integrating the loss and grief in participants' lives and a step-by-step guide to acceptance of the loss and to finding meaning for life in the future.

Other groups are often offered by public agencies and are led by professionals with some competence with grieving processes, group processes and grief- and trauma-reactions.

Some open groups are run by leaders who have their own experience of loss under similar conditions. When newcomers share their experience this might reactivate experiences for those who have been in the group for a while and thereby prevent progress in their own lives.

Those bereaved after suicide need to be together with others with the same experience. They have some extra dimensions in their grieving process since it is often combined with guilt - shame - and reconciliation. Those who have been bereaved as a result of violence, experience some of the same dynamics.

In this article there are also examples of interventions like offering school classes to share experiences about loss and grieving and collective gatherings after severe accidents. Such interventions may also be defined as interventions that work with grieving processes. 
for etterlatte ved dødsfall med ulike årsaker. Jeg vil også omtale situasionsbestemte gruppeintervensioner, som ikke dekkes av den vanlige sorggruppedefinisjonen, men som representerer tiltak som kan bidra til å gi mening og fotfeste for dem som er etterlatte.

\section{Hva er sorggrupper?}

Sorggrupper er en fellesbetegnelse for ulike typer grupper for sørgende, avhengig av målsetting for gruppene. Lederskap, struktur og innhold kan dermed også være forskjellig. Vi skjelner mellom tre hoveddefinisjoner: terapeutiske sorggrupper, faglig styrte sorggrupper og likemanns-/selvhjelpsgrupper (Thuen, 1995). De terapeutiske sorggruppene har utvikling, endring og integrering som målsetting og ledes av en fagperson med spesiell kompetanse, ofte psyko-

Det har vært ulike måter å forstå sorgens forløp på log eller psykiatrisk sykepleier. Terapeuten er gruppeleder og har kompetanse til å vurdere den enkeltes behov for å komme videre i sorgarbeidet sitt.

De to andre gruppeformene preges mere av at deltakerne deler sine erfaringer og opplevelser og fungerer som et sosialt støttenettverk. De faglig styrte gruppene ledes gierne av prest eller diakon, som har noe kompetanse innenfor sorgarbeid, gruppeprosesser og sorg-/traumereaksjoner. Selvstyrte grupper eller selvhielpsgrupper ledes av etterlatte selv og kan supplere sosial nettverksstøtte og faglig oppfølging (Dyregrov \& Dyregrov 2007; Ranheim, 2009). Det er ulik praksis i forhold til hvorvidt sorggruppene etableres ut ifra dødsårsak eller ut ifra relasjon til avdøde. Ofte er det blandete grupper dersom søkningen til sorggruppetilbudet er for liten til å organisere mer spesialiserte grupper. Frivillige organisasjoner som er dannet på bakgrunn av en spesiell dødsårsak, vektlegger naturlig nok homogene grupper der dødsårsaken til avdøde bestemmer deltakelse. I 2012 ble det publisert en undersøkelse om omfang og organisering av sorggrupper i Norge (Johnsen \& Dyregrov \& Dyregrov). Resultatene viser at de fleste sorggruppetilbud drives av det offentlige, i hovedsak av menigheter, kommuner og sykehus; deretter kommer frivillige organisasjoner. Noen av organisasjonene har drevet sorggrupper helt siden 1980-tallet.

Varigheten av sorggruppene varierer, men felles for de fleste er at det er et fastsatt tidspunkt for start og avslutning. Gjennomsnittlig varighet for gruppene er 7 til 8 måneder. De fleste av dem er selvhjelpsgrupper, der målsettingen er å legge til rette for «støtte og bekreftelse fra andre i samme situasjon» og «å dele følelser og sette ord på sorgen».

\section{Sorg}

Ettersom sorgen er en del av menneskers liv, tar vi det for gitt at sorgen tar den plassen og bruker den tiden som er nødvendig. Det har vært ulike måter å forstå sorgens forløp på. På 6o-tallet var den vanlige oppfatningen at sorgens forløp følger faser som benekting, sinne, tilpasning, depresion akseptering/forsoning (Kübler-Ross, 1969). Nyere sorgforskning beskriver den naturlige sorgprosessen som en veksling mellom tapsorientering og reparasionsorientering (Stoebe \& Schut, 1999). Samtidig med at den etterlatte er påvirket av sorgen, gienopptas hverdagslige giøremål. Ettersom tiden går, redefineres roller i familien og i nettverk, i perioder er

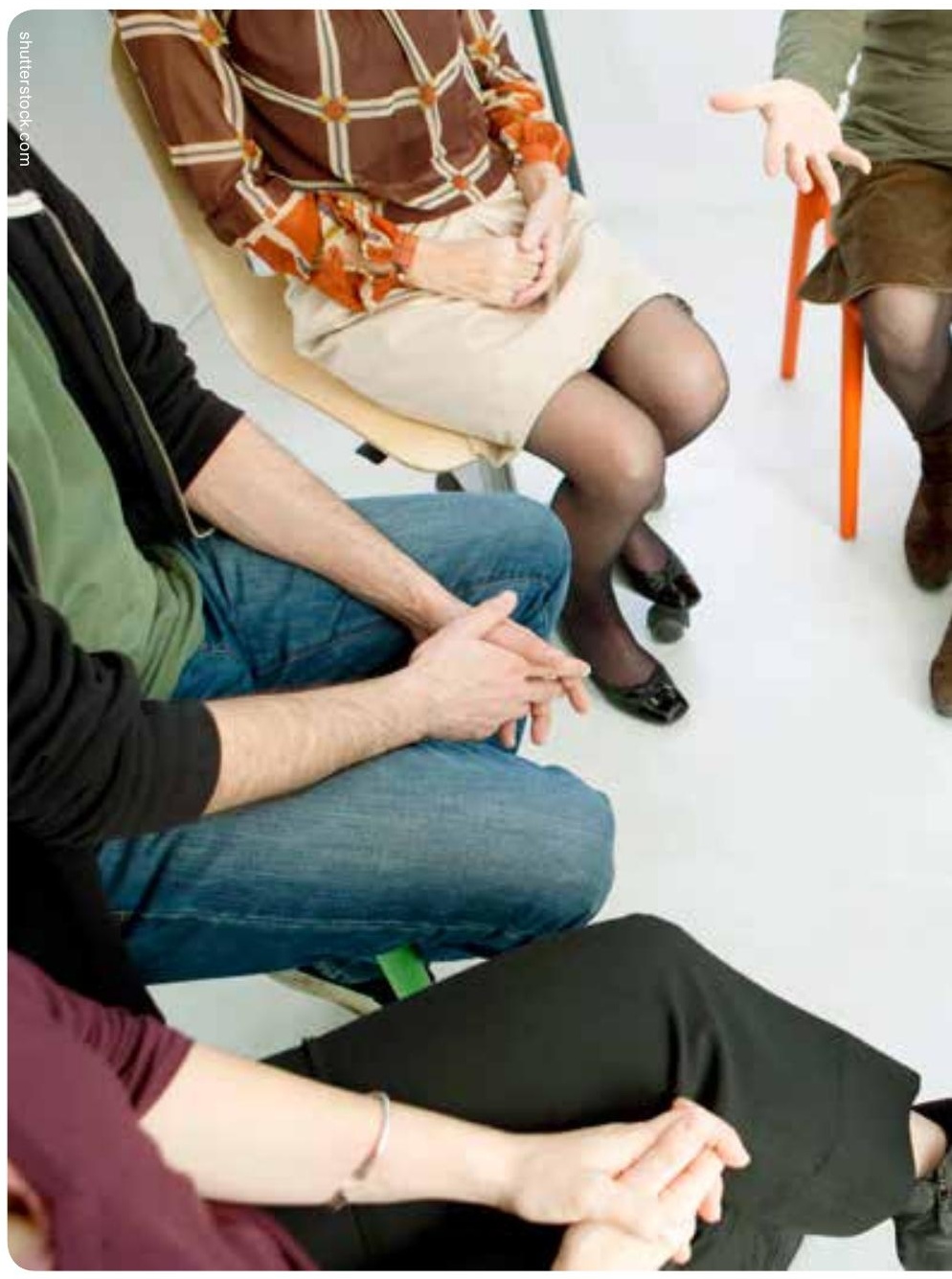

det benekting og unngåelse av sorgen for så å utforme nye roller og identitet. Det er en pendling mellom konfrontasjon med tapet, det å kjenne på sorgen og det å orientere seg mot daglige giøremål for å tilpasse seg situasionen etter tapet. Tilknytningen til avdøde blir en del av livet videre. Tidligere la man vekt på at sorgarbeidet innebar distansering til avdøde i stedet for integrering i det videre livet.

Nyere sorgforskning har tydeliggiort den kompliserte sorgen, der arbeidet med gienvinning av livskvalitet stopper opp og der adferdsmønstre stivner med minner og rituelle handlinger. Intensiteten i smerten vedvarer, og det er store vansker med å akseptere tapet. Det er diskutert hvorvidt komplisert sorg skal defineres som en ny psykiatrisk diagnose. Da må sorgforlengelsen ha vart i minst seks måneder. (Brewin, Bryant et al., 2013). Den kompliserte sorgen kan kjennetegnes både som forlenget sorg og kronisk sorg. Komplisert sorg synes ofte å være en konsekvens av traumatiske hendelser. Etterlatte sliter ofte med forlenget sorg og tap av livskvalitet (Dyregrov, 2003; Dyregrov \& Dyregrov, Kristensen, 2014; Shear 2015).

Ettersom både dødsårsak og relasioner er av betydning for sorgarbeidet, vil jeg i det følgende reflektere over hvilke typer tilbud som vil være hensiktsmessig for de ulike tapsopplevelsene. Det er viktig å være oppmerksom på forskjellen mellom forventet død og brå uventet død, ettersom sorgforløpet kan være svært forskjellig. 


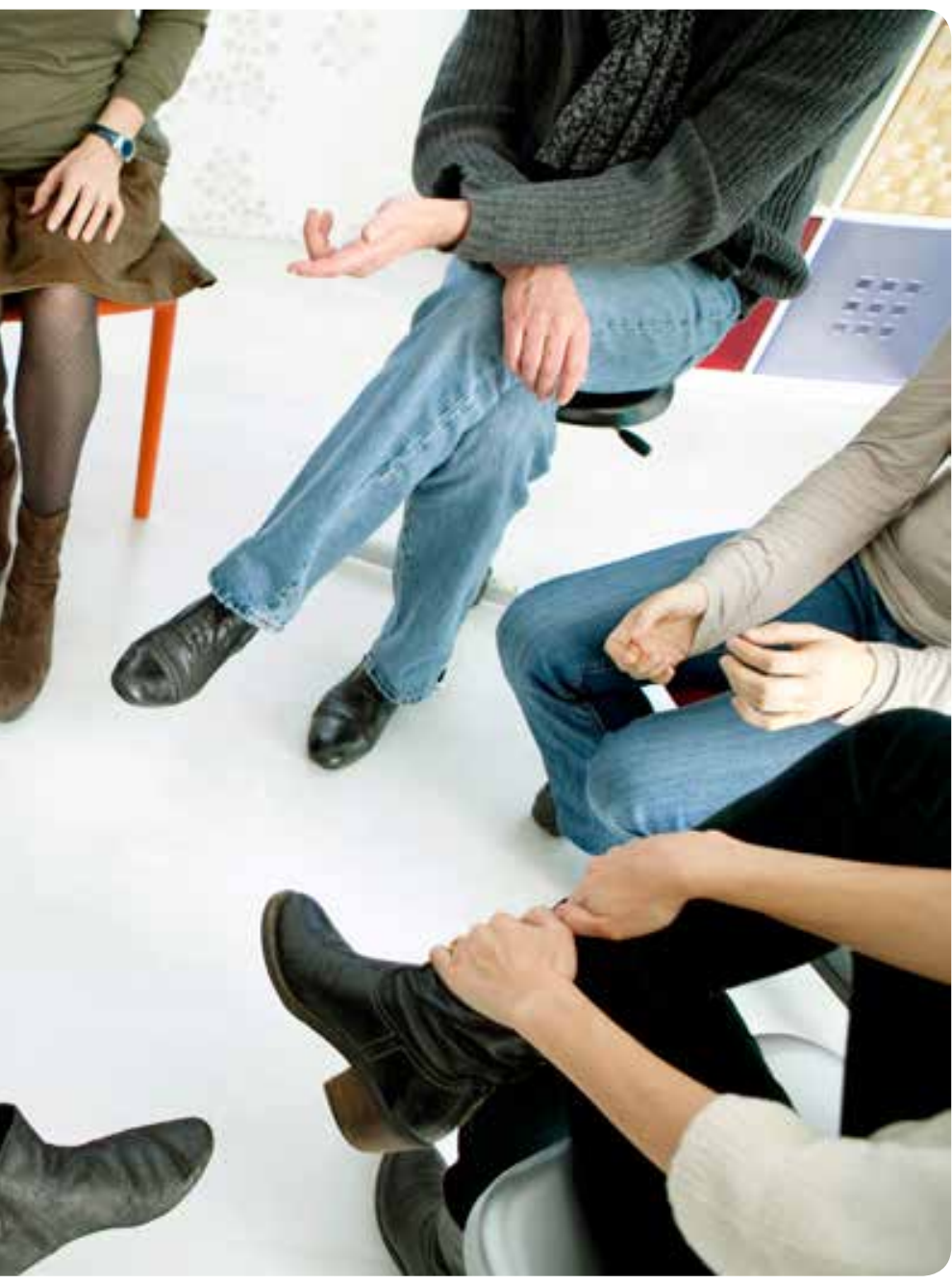

Nyere sorgforskning har tydeliggjort den kompliserte sorgen

\section{Sorggrupper ved forventet død} Ved forventet død etter et langt sykeleie eller dersom dodsfallet er knyttet til alderdom, vil de etterlatte ha tid til å forsone seg med døden og de vil ha mulighet til å ta avskied. Dette preger naturlig nok sorgforløpet. Etterlatte som har fulgt en alvorlig sykdomsutvikling med døden til følge, kan ofte ha behov for å dele erfaringer fra denne perioden, ikke bare snakke om tapet og sorgen, men å dele erfaringer fra motet med helsevesen, hjemmesykepleien, tilrettelegging eller mangel på sådan med tanke på den døendes livskvalitet. De kan ha opplevd at helsevesenet har lagt ensidig vekt på den medisinske behandlingen og vurderingen. For den døende kan dette også medføre opplevelse av sterk eksistensiell ensomhet den siste tiden av livet, fordi de nærmeste ikke våger å samtale om at livet går mot slutten.

I min tid som spesialpsykolog ved somatiske avdelinger husker jeg et mote med en gammel mann som visste at livet gikk mot slutten, men ingen snakket med ham om doden og heller ikke om livet som gikk mot slutten. «Da jeg satt i konsentrasjonsleir og tenkte på dem hiemme, hadde jeg et håp. Nå er jeg mere ensom enn jeg var den gangen, ettersom jeg ikke har noe håp lenger.» Vi inviterte hele familien til å komme til sykesengen. I alles påhor sa ansvarlig behandler at det var kort tid igjen av livet. Den gamle hustruen brast i gråt, la armene rundt ham og sa: «leg har ikke villet forstå det, men nå forst tar jeg inn alvoret. Nå får jeg en mulighet til å takke deg for alle de årene vi har hatt sammen.» På sporsmål om hva slags minner de voksne barna hadde fra oppveksten, svarte de: «Vi pleide å synge, når vi gikk på tur.» Dermed begynte de å synge, forst en tursang, for så å fortsette med hele repertoaret. Denne enka kunne gå videre og tenke tilbake på det verdifulle eksistensielle motet hun fikk oppleve med sin mann. De voksne barna fikk bidra til at den døende fikk oppleve en bro til gode minner fra deler av sitt levde liv. De nærmeste fikk en felles opplevelse, som de senere kunne dele i sorgen.

Dette er et eksempel på tilrettelegging som forbedrer den døendes livskvalitet, som bidrar til fellesskap i stedet for å forsterke alle berørtes ensomhet. Det kan i denne sammenhengen forståes som en type sorggruppe at både den syke og de pårørende kan ta farvel med livet, og ved sykesengen sammen bygge bro mellom livet som de har levd sammen og døden som kommer til å skille dem ad. Det blir i for liten grad lagt til rette for at døende og de som skal leve videre kan støttes frem til dødens terskel. Sorggrupper kan bidra til å fylle et tomrom for mange som ikke fikk denne nødvendige støtten, og som kan hende heller ikke har nær familie å støtte seg til. Gruppene kan bli en arena der anger, skyldfølelse og ensomhet kan få utløp og bli delt med andre som heller ikke har fått nødvendig bistand og støtte til felleskap ved avslutningen av livet. Etter hvert vil gruppemedlemmene naturlig vektlegge det å skape nytt livsinnhold. Jeg har hørt utsagn som: «Samvær med andre i sorggruppen er viktig for meg, fordi det er blitt så tomt rundt meg. Mange av de gamle vennene er døde, og nå som jeg har mistet min ektefelle, har jeg mistet fellesskapet med vårt gamle nettverk.» I en slik situasjon stilles det store krav til gruppelederen som bør stimulere deltagerne til å holde kontakten med eget sosialt nettverk, slik at ikke sorggruppen blir en erstatning. Denne type sorggrupper vil høre innunder faglig styrte grupper, der målsettingen er å dele erfaringer fra tiden ved dødsleiet, via tomheten som kan prege livet etterpå og etter hvert hvordan man kan få nye fremtidsperspektiver.

Mange kan fortelle at de har hatt stort utbytte av likemannsgrupper. Gruppen kan gi mulighet for å delta på sosiale tilstelninger, som for eksempel å gå på teater eller restaurant sammen med andre i samme situasjon. Det kan være så konkret som å utveksle erfaringer om hvordan finne nye mestringsområder i livet.

En eldre mann mistet sin hustru etter et langt smertefullt sykeleie, nær 50-års bryllupsdag. Han inviterte en god venn til middag noen uker etter dodsfallet og serverte stekt fisk og agurksalat. Han sa: «Etter 50 års samliv, er det nå mitt ansvar hvordan resten av livet mitt skal bli. leg har bestemt meg for å lage mat selv, og har begynt å folge oppskrifter i kokeboka. Ieg har begynt på A - derfor kan jeg i dag servere agurksalat.»

Sorggrupper for eldre mennesker som har mistet sin ektefelle, kan i en periode være et svært viktig støttetilbud, der ensomheten kan deles med andre i tilsvarende situasion. Dagens familier er ofte spredt over store geografiske 
avstander, og muligheten for å støtte en bestemor eller bestefar som er blitt alene, kan ofte være begrenset. En sorggruppe kan få funksjon som en utvidet familie. Denne type sorggrupper trenger ikke ledelse av personell med spesifikk terapeutisk kompetanse.

\section{Sorggrupper ved brå død}

Brå død kan skyldes sykdom slik som hjertelidelse-ulykke, fritidsulykker, arbeidsulykker og trafikkulykker der det er ytre omstendigheter som forårsaker dødsfallet, eller vold. Felles for etterlatte ved uventede dødsfall er at det kan ta tid før tapet blir opplevd som virkelig.

En tenåring fortalte om pappa, som omkom i en brann dagen etter at han reiste hiemmefra. Etter planen skulle han være borte i tre uker. Familien fikk dodsbudskapet. Kista kom hiem. Begravelsen var giennomfort. Men forst den dagen pappa var forventet hiem ble tapet virkelig. Han kom jo ikke.

Noen ganger kan det være klanderverdige forhold som forårsaker ulykkene, enten ved manglende sikkerhet eller risikoadferd. Omstendigheter ved dødsfallet kan virke forstyrrende på sorgarbeidet ettersom mange spørsmål melder seg. Det er viktig at all tilgiengelig informasion blir lagt frem, slik at grubling over hendelsen kan avdempes. Faktainformasion kan ha en trøstende effekt.

I en sorggruppe for etterlatte ved dødsfall av denne typen vil det være viktig at lederen er oppmerksom på innholdet i tanker som legges frem, slik at man unngår å spinne videre på antagelser og fantasier. Det vil være av betydning å bistå de sørgende i å skille mellom hva de vet og hva de tror om hendelsen, og eventuelt oppfordre dem til å ta kontakt med for eksempel akuttmottaket på sykehuset eller politiet eller andre som kan gi korrekte

Faktainformasjon kan ha en trøstende effekt opplysninger om omstendighetene rundt dødsfallet. Noen
ganger kan spørsmålene komme opp lenge etter et dødsfall. Sorggruppe for etterlatte ved brå dødsfall av denne typen kan være både terapeutiske og fagstyrte. I denne situasjonen er imidlertid likemannsgrupper lite egnet.

\section{Sorggrupper for barn og unge}

Ved de aller fleste brå dødsfall er barn involvert som etterlatte. Det følgende eksemplet tar jeg med for å illustrere betydningen av åpenhet der barn er etterlatt. Dette dreier seg ikke om sorggruppe i tradisjonell forstand, men om en klassesamling og dens konsekvenser for elevgruppen.

Klassen var samlet etter begravelsen til pappaen til en gutt $i$ klassen. Faren var omkommet $i$ en småbåtulykke, og vi hadde lagt til rette for at 12-åringen ble tatt med i redningsskoyta til ulykkesstedet. Politimannen som hadde vært med på leteaksionen var også om bord og kunne fortelle gutten hvordan været hadde vært og hvordan bølgehøyden hadde bidratt til at båten til faren hadde kantret. Stromforholdene på ulykkesstedet kunne også forklare hvorfor far ikke hadde klart å svømme i land. I ambulansebilen etterpå fikk gutten ligge på båra for å få et inntrykk av hvordan ambulansepersonalet hadde forsøk å redde farens liv. Ved akuttmottaket fikk han se behandlingsrommet hvor faren var blitt tatt i mot og fikk forklart hvordan sykepleierne hadde brukt defibrillatoren. Deretter utbrot han: «Da har dem jo giort mye for pappa. leg trodde de bare så på ham og så sa: Nå er han dod.» Han så faren sin på båra, som var trillet ut av kjølerommet, tok på ham og syntes han var veldig kald. Neste gang tok han med lue og votter til pappaen sin. Hele klassen motte til begravelsen, sammen med klasseforstander og noen foreldre. Deretter var det klassesamling $i$ et privat hiem. Gutten fortalte om båtulykken, om hvordan det var å ta på den kalde faren sin og hvordan det var å se ham livlos. leg spurte om noen andre hadde sett dode mennesker, og en gutt svarte bekreftende. Et par uker etterpå fikk jeg et brev fra moren til denne gutten. Hun fortalte at han hadde kommet hiem og fortalt om samlingen. Han var ny i klassen og trodde han var alene om å ha mistet faren sin. Faren hans var omkommet $i$ en trafikkulykke, der gutten hadde vært med i farens bil. Etter denne hendelsen hadde han blitt svært innesluttet og trist. Moren skrev: "Etter klassesamtalen er han blitt en helt annen gutt. Han forteller om tankene sine, om savnet etter faren sin, om ulykken. Jeg har fått en glad gutt etter at dere snakket åpent om døden.

En klassesamling kan bidra til sorgarbeidet, selv om det ikke er en sorggruppe som fungerer over lengre tid. Erfaringen forteller også noe om betydningen av å innhente faktaopplysninger om hendelsesforløpet på en slik måte at berørte barn forstår sammenhengen.

I tillegg til oppfølging av barn og unge i en akutt fase, vil det være viktig å gi strukturerte sorggruppetilbud. Slike tilbud gis blant annet av Kreftforeningen og enkelte sykehus. Det er ulikt program for hver samling, og det er samtaler om det å miste noen, endringer i hverdagen og ulike folelser man kan oppleve. Barna og ungdommene blir delt inn i grupper etter alder: 3-6 år, 7-10 år, 11-13 år og 14-17 år (https://kreftforeningen.no/vare-tilbud/kurs-og-grupper).

Ved Senter for krisepsykologi i Bergen gir sorggruppen for barn og unge muligheter for samtale med andre i samme situasion. Det gis mulighet til å sette ord på sine tanker og erfaringer og lytte til andres. Dette bør skje under kyndig veiledning og ulike samtaletema kan tas opp, slik som savnet over tid, venners reaksjoner, skolens håndtering, hvordan mestre skolearbeid og smertefulle minner, etc. Det blir benyttet enkle samtalemetoder muntlige og skriftlige - som er alderstilpasset for jenter og gutter (www.krisepsyk.no).

Sorggrupper for barn krever kunnskap om barns emosjonelle og kognitive utvikling, derfor vil metodevalget for gruppene avhenge av alderstrinnet. Gruppene bør defineres som terapeutiske grupper som ledes av kvalifisert fagpersonell.

\section{Sorggrupper etter selvmord}

Sorgen etter selvmord omfatter ikke bare tapet, men også alle spørsmål og undring over det som førte frem til at livet ble avsluttet. Mange av disse spørsmålene vil det aldri finnes svar på, og de etterlatte må ofte gå igjennom en krevende forsoningsprosess. Mange etterlatte kan fortelle at det er for vanskelig å delta i en blandet sorggruppe fordi det er så mange spørsmål og tunge tanker som kommer i tillegg til sorgen over tapet av den avdøde. Så langt som mulig bør det derfor tilbys egne sorggrupper for selvmordsetterlatte. Sorggrupper som omfatter etterlatte ved selvmord kretser ofte rundt emosionelle tema som skyld, skam og forsoning. 
Det er en ekstra dimension ved selvmord, ettersom det så ofte melder seg spørsmål om noe kunne vært giort annerledes, noe man burde forstått, noe man burde snakket om. Sorggrupper for etterlatte ved selvmord stiller derfor store krav til profesjonell ledelse. Gruppen bør være en lukket gruppe med avtalt tidsramme, der målsettingen er å fremme aksept av tapet, refleksion og forsoning med døden og omstendighetene rundt selvmordet, og støtte til å gienerobre områder i livet som kan gi livskvalitet, selv om grunnlaget for å gå videre er brutalt endret.

Mange som har opplevd selvmord, kan også fortelle om verdifull støtte de har mottatt giennom likemannskontakt, særlig for å komme igjennom den første tiden etter selvmordet. Det er viktig at de som driver likemannsarbeid også opprettholder andre interesser og engasjement i livet, slik at ikke det å være selvmordsetterlatt blir deres eneste identitet.

leg tenker med bekymring på et internasjonalt mote der jeg møtte et ektepar hvis eneste perspektiv så ut til å være at de var etterlatte ved selvmord. T-skjortene deres var påtrykt bilde av sonnen som hadde tatt livet sitt for flere år siden. De bidro sikkert vesentlig til å rette fokus på etterlattes situasjon etter selvmord, men det ble deres viktigste identitet slik at de mistet perspektivet på hva livet for ovrig kunne innebære.

\section{Sorggrupper ved andre brå og uventede dødsfall}

Dersom dødsfallet skyldes en voldshandling, står etterlatte overfor en krevende forsoningsprosess, ettersom tapet er forvoldt av et annet menneske. Selve dødsårsaken kan bidra til komplisert sorg, og i tillegg blir sorgarbeidet ofte forstyrret av de konsekvensene voldshandlingen får i form av rettssak og medieoppslag. Sorgen får ofte ikke rom fordi så mye annet krever oppmerksomhet. Sorgprosessen blir da forskjøvet, og det er fare for at støtten i eget nettverk svekkes fordi andre er gått videre i livene sine og har fått smerten over tapet på avstand når den etterlatte endelig er klar til å komme videre i sin egen sorgprosess. Det kan være vanskelig å danne sorggrupper for etterlatte ved drap på grunn av geografisk avstand mellom de etterlatte. Men det kan legges opp til årlige samlinger, som kan gi en viss mulighet for dem som er berørt til å treffes. Stine Sofie Stiftelsen har arrangert et slikt møtepunkt i flere år.

\section{Relasjonsbaserte sorggrupper}

Foruten dødsårsak og omstendigheter ved et dødsfall er det av stor betydning hvilken relasion de etterlatte hadde til avdøde. I en familie vil ofte alle medlemmene ha sin egen ensomme sorg selv om de sørger over samme person.

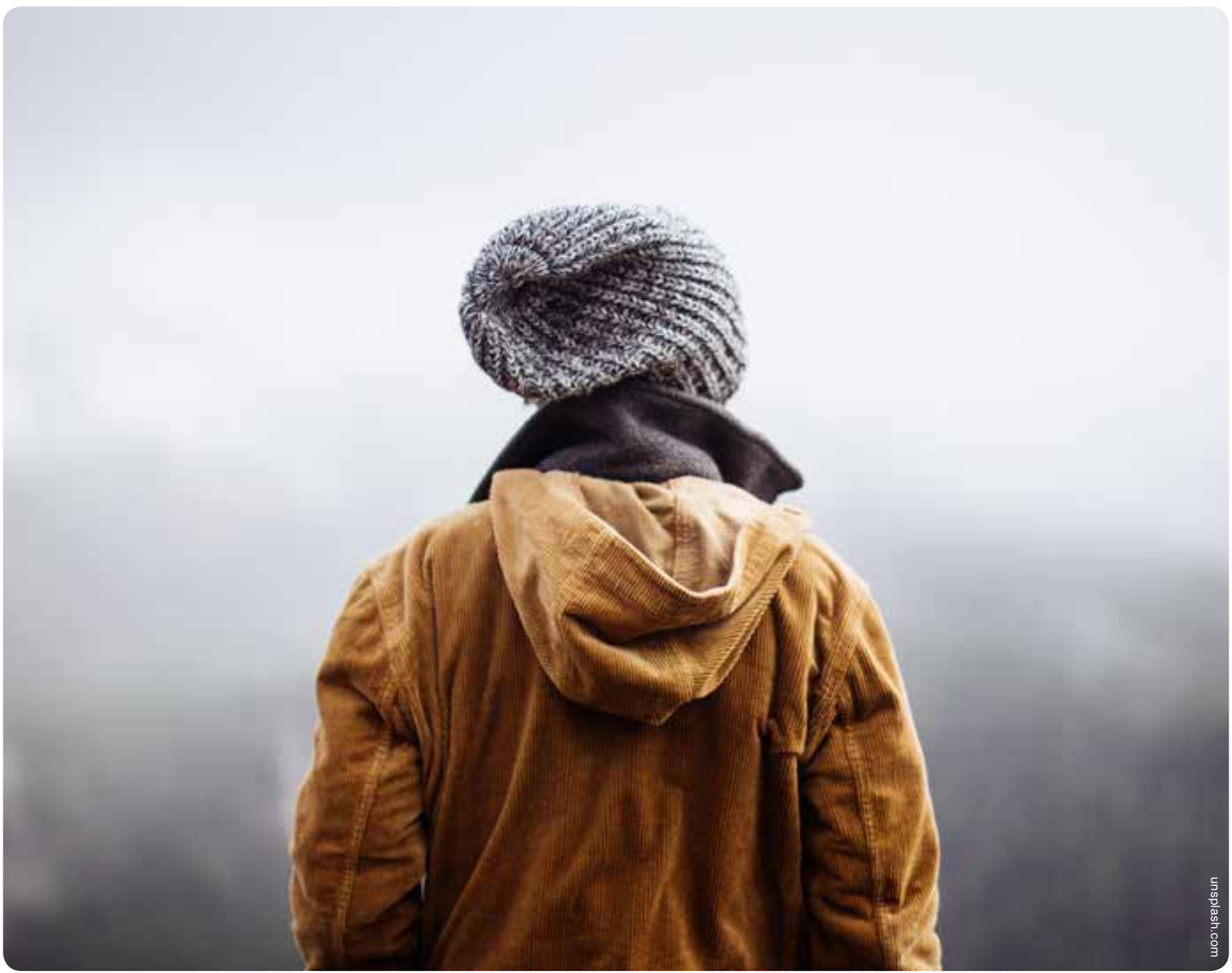


Dette bruddstykket fra en samtale beskriver forskjeller i forhold til den emosionelle relasionen: «leg vet ikke hvordan det er å være mor som har mistet en datter, men jeg vet hvordan det er å ha mistet en soster.

Flere ganger har jeg hort gienlevende søsken si: «Når jeg moter andre mennesker, så spor de alltid hvordan mamma og pappa har det. Ingen spor hvordan det er for meg.

Besteforeldre er på mange måter en glemt gruppe. De forventes å stille opp for den nærmeste familien som støttepersoner ved tap og sorg, men ofte er det lite rom for deres egen sorg over tapet av et barnebarn eller tapet av en voksen sønn eller datter. Ved de kollektive samlingene etter terrorangrepene i Norge 22. juli 2011 var vi klar over besteforeldres behov for å få være med, men det ville sprengt logistikkrammene for samlingene, og det var med tungt hierte vi måtte begrense deltagelsen (Dyregrov \& Dyregrov, Straume, Bugge 2014). De gruppene som ble satt sammen ved de kollektive samlingene i denne situasionen kan ut i fra en videre definisjon også betraktes som sorggruppearbeid. De ble satt sammen etter relasjon til avdøde; søskengrupper, foreldregrupper og partnergrupper. Samlingene ble giennomført fire ganger fordelt over en periode på 1 1⁄2 år. (Dyregrov, A., Dyregrov, K., Straume, M., Bugge, R.G. 2014). Tilbakemeldingene på samlingene tyder på at det er av stor betydning å få treffe andre som har mistet sine under de samme omstendighetene. Lignende tilbakemeldinger har vi også registrert etter andre større ulykker, slik som Sleipnerforliset i 1999 og Togulykken ved Åsta i

\section{Sæerlig ved} selvmord er det en myte at sorgen forener
2000. Hensikten med slike samlinger er på ingen måte å erstatte de etterlattes eget nettverk, men samlingene kan skape en arena for fellesskap der alle kjenner til bakgrunnen og der de berørte kan stille spørsmål og dele tanker. Etterlatte finner ofte trøst ved å møte noen som kan fortelle noe om den de selv har mistet.

I vår tid er det ofte kompliserte familieforhold. Det er viktig å ivareta også steforeldre og inngiftede partnere. En slik tilnærming krever kompetanseheving hos aktuelt helsepersonell. Etterlatte strever ofte med de mange hvorfor. Jeg tror mange kunne slitt litt mindre om det hadde vært bedre oppfølgingsrutiner for familier. Det ensidige fokuset på individets sorgprosess kan noen ganger oke splittelsen i familier og forsterke negative kommunikasjonsmønstre. Berørte familiemedlemmer bør bli innkalt til en akutt samtale og senere oppfølgingssamtaler. Jeg sier med vilje innkalt og ikke tilbudt. I somatikken spør vi aldri folk som har fått en lungebetennelse om de ønsker å ta i mot tilbudet om rontgenundersøkelse. I somatikken respekterer vi gitte behandlingsrutiner. Innkalling til familiesamtale bør være en rutinemessig forebyggende intervension. Familien er i en dyp krise der de enkelte medlemmene kan ha ulik forståelse av hva som har skjedd. Kommunikasjonsmønstret kan bli svært komplisert, unngåelsesreaksjoner mellom familiemedlemmer kan utvikle seg til vedvarende konflikter. Tidlige familiesamtaler kan derimot bidra til åpen og god kommunikasjon og hjelpe familien til å finne nye roller (Dyregrov \&, Dyregrov, Kristensen, 2014). Denne type intervension kan også forstås som en type sorggruppe, ettersom målsettingen er å bidra til å gi familiesystemet mestringsmuligheter slik at kontakt og kommunikasjon kan opprettholdes. Særlig ved selvmord er det en myte at sorgen forener. Ulik forståelse av det som har skjedd og ulik oppfatning av familiehistorien kan sprenge samholdet. Ofte er det ingen i familien som har styrke til å holde systemet sammen, kan hende mangler også den giensidige tilliten. Derfor er det viktig at familien blir bedt om å møte samlet. Slike familiesamlinger krever god kompetanse både om reaksjoner og gruppedynamikk i familiesystemer.

\section{REFERANSER:}

Dyregrov, A., Dyregrov, K., Straume, M., \& Gronvold Bugge, R. (2014). Weekendfamily gatherings for bereaved after the terror killings in Norway in 2011. Scandinavian Psychologist, 1, e8. http://dx.doi.org/10.15714/scandpsychol.1.e8

Dyregrov, K., Plyhn,E. \& Dieserud, G. (2010). Etter selvmordet. Veien videre. Oslo: Abstrakt forlag.

Dyregrov, A. og Straume, M. (2008). "Kollektiv ivaretakelse etter katastrofer. Erfaringer fra Sleipner-ulykken». i Dyregrov, K. og Dyregrov A. (red.) «Krisepsykologi i praksis». Oslo: Fagbokforlaget.

Tohnsen, I, Dyregrov, A. \& Dyregrov, K. (2011). Omfang og organisering av sorggrupper i Norge. Tidsskrift for Norsk Psykologforening, 48 (12), 1178-1183.

Kubler-Ross E. (1969). On Death and Dying. Macmillan, New York.

Shear K. Complicated Grief, N Engl I Med 2015; 372;2.

Stroebe, M. \& Schut, H. (1999). The Dual Process Model of coping with bereavement: Rationale and description. Death Studies, 23, 197-224. doi: $10.1080 / 074811899201046$.

Stroebe, M. \& Schut, H. (2010). The dual process model of coping with bereavement: A decade on. Omega, 61, 273-289.

Thuen, F. \& Skutle, A. (1995). Evaluering av samarbeidsprosiektet Sorg og Omsorg. Del 1: En metodologisk tilnærming. Tidsskrift for Norsk Psykologforening, 32, 328-336.

https://kreftforeningen.no/vare-tilbud/kurs-og-grupper/ostlandet/oslo/ sorggrupper-for-barn-og-ungdom

http://www.krisepsyk.no/sorggrupper-barn

http://psykologisk.no2014/og

www.sorggrupper.no

http://stinesofiesstiftelse.no

Levert 15.03.15, revidert 24.3.15, godkjent 24.3.15

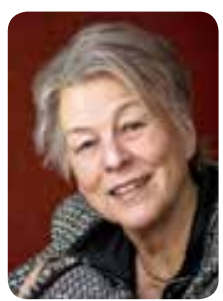

RENATE GRONVOLD BUGGE har vært rådgiver for organisering ved oppfølging etter flere av de store ulykkene i Norge siden 1986 og vært leder av barne- og ungdomspsykiatrien i Vest- Agder i mange år, tidligere direktør ved RBUP. Hun leder firmaet KOL AS: Krise - Organisasjon - Ledelse, og er medarbeider ved Senteret for krisepsykologi i Bergen. I 2008 ga hun ut boka «Når krisen rammer barn og unge». 